\title{
11. Languages of neoliberal critique: The production of coercive government in the Northern Territory intervention
}

\author{
Melissa Lovell
}

\begin{abstract}
A critical approach to the study of rhetoric can help us to better understand the patterns of political discourse that normalise coercive approaches to government. This critical approach is especially necessary for the study of the governance of Australian Aboriginal Affairs. Historically, representations of Aboriginal peoples as uncivilised, violent and irrational have played a crucial role in the legitimation of colonialist policies. The work of postcolonial scholars has led to a growing acceptance among academic circles of the constructed nature of our knowledge about culture and identity. Furthermore, we can understand the process of identity construction - of ourselves and other groups - as a social process that is 'bound up with the disposition of powerlessness in each society' and which therefore has an impact on 'the legislation of personal conduct, the constitution of orthodoxy, [and] the legitimization of violence' (Said 2003: 332).
\end{abstract}

The study of political rhetoric clearly needs to take into account the way that the subjects of government policy — including Aboriginal people - are represented within political discourse. Scholars of rhetoric have long grappled with the relationship between rhetoric and knowledge. In general, scholars have been divided between those who define knowledge as 'justified true belief', and those with a less positivist orientation who have sought to understand the way that knowledge is socially created (Foss and Gill 1987: 385). The latter group often uses the work of Michel Foucault to develop analyses of the role of rhetorical frameworks - or discursive formations - in the production of knowledge and representation (Biesecker 1992; Cooper 1988; Foss and Gill 1987: 392; McKerrow 1989). As Raymie McKerrow explained in his influential 1989 article, a critical rhetoric seeks to understand the way that the normalisation of language is used to maintain the status quo and to structure power relationships. McKerrow argues that 'the initial task of a critical rhetoric is one of re-creation - constructing an argument that identifies the integration of power and knowledge and delineates the role of power/knowledge in structuring social practices' (McKerrow 1989: 102-03).

It is this critical approach to rhetoric that I adopt in this chapter. In particular, I seek to examine the relationship between the production of knowledge and 
the legitimation of coercive public policy approaches in the field of Aboriginal Affairs governance. My analysis focuses on the formal political debate over the introduction of Australia's Northern Territory Intervention, which was designed to protect Aboriginal children from widespread abuse and neglect in remote NT communities (Howard and Brough 2007). Often linked to a neoliberal economic development paradigm, the Intervention was the target of much criticism (Concerned Australians 2010: 8; Dodson 2007; Tangentyere Council 2007). Many people were concerned that the Intervention was a strike against the political and group rights of Aboriginal people, and saw the policy as an assimilationist, paternalist and colonialist development in Australian Aboriginal Affairs policy (Conor 2007; Macoun 2011; Manderson 2008; Mazel 2009). Federally, however, there was general consensus within the major political parties over both the necessity of the policy and its more coercive elements. My analysis focuses on this parliamentary discourse, as well as other political speeches that sought to justify coercive approaches to Aboriginal Affairs governance. I argue that the legitimation of coercive governance depended upon the development of new forms of knowledge about both Aboriginal people - as the objects of governance - and the limitations of alternative techniques for Aboriginal governance. Neoliberal conceptions of good governance and the ideal citizen were employed to produce new forms of knowledge about the field of Aboriginal Affairs governance.

\section{Coercion and neoliberal government}

A critical rhetoric attends to the 'discourses of the dominant'. It creates a space to problematise these discourses and open up 'spaces of invention' for those who read them (Phillips 2002: 342). Drawing on Foucault's scholarship, critical rhetoric scholars make discursive practice the locus for investigation of social processes. In particular, they consider the way that knowledge and power relations are closely interwoven (Cooper 1988: 10-15). In this chapter, I ponder the question of whether, and in what manner, the knowledge produced in debates over the NT Intervention might be linked to identifiably neoliberal politics. Furthermore, I consider whether it is reasonable to suggest that this neoliberal paradigm is responsible for the recent normalisation of coercive approaches within Aboriginal Affairs governance.

I derive the above questions from the particular situation of my case study, rather than from broader theoretical principles. There are two relevant contexts. The first of these is the idea - common among scholars of Australian and Aboriginal Affairs policy - that Australia has shifted toward a neoliberal policy paradigm in recent decades. Neoliberalism is commonly understood as an elite ideology whose proponents have sought to permanently transform Australian government. 
Proponents of neoliberal politics are hostile towards an 'interventionist' welfare state, which they see as both economically inefficient and morally damaging to citizens because it encourages a culture of dependency on government services (Rose and Miller 1992: 198). Neoliberals adopt a utopian conception of capitalism; they see liberty as a condition that individuals can best pursue through ordinary participation within a free market (Cahill 2007: 228). The NT Intervention has been described as part of a broader ideological shift within Aboriginal Affairs policy towards a neoliberal policy paradigm (Altman 2007: 2; Hinkson 2007: 6; Walter 2010: 126-27). This paradigm has been characterised by antipathy toward elements of a rights-based policy agenda, such as the recognition of native title and Aboriginal self-determination. It sought to bring legislation, policy and the institutional framework in line with the government's broader neoliberal agenda by emphasising the principle of mutual obligation as a replacement for the principle of self-determination (Anderson 2008: 766).

The second relevant context is the increasing normalisation of coercive approaches to governance in Aboriginal Affairs policy. When I describe the Intervention as coercive, I mean that the federal government used its authority to compel Aboriginal people to act in particular ways and to substantially reform the institutional and administrative structure of remote Aboriginal communities. The early stages of the NT Intervention, which drew on the language of military intervention and deployed Australia's military to occupy remote NT Aboriginal communities, was a potent display of state power and of the federal government's ability to coerce Aboriginal citizens (Rundle 2007: 37, 43). Once established, the Intervention encompassed most aspects of daily life in NT Aboriginal communities. It was described by then Prime Minister John Howard as 'radical, comprehensive and highly interventionist' and as a 'sweeping assumption of power and a necessary assumption of responsibility [by the federal government]' (Howard 2007: 70). Some key measures — outlined in three parliamentary Acts - included the compulsory acquisition of Aboriginal townships by the government through five-year leases; the dismantling of the permit system for townships on Aboriginal land; and income management reforms that prescribed the way that Aboriginal people spent their incomes, and which linked social security payments to children's school attendance. There were also a number of important measures linked to the government's law and order agenda. These included the application of heavy penalties for use of alcohol and pornography, the removal of customary law and cultural background as considerations during bail and sentencing, and an increased police presence in Aboriginal communities (Parliament of Australia 2007: 23). With the initial 'stabilisation' phase of the Intervention complete, the program has moved into a long-term 'development' phase known as Stronger Futures 
in the Northern Territory (Australian Government 2011). The Stronger Futures legislation firmly entrenches many of the coercive elements of the original intervention in Australian social security policy.

We would intuitively expect these two contexts to be related in some way. Many critics of neoliberal ideology would be unsurprised at the idea that a neoliberal politics could restructure the relationship between governments and Aboriginal peoples towards a more coercive set of power relations. Indeed they might find this idea self-evident, and further explanation of this relationship to be redundant. I believe, however, that it is important to drill down into the detail of the relationship between neoliberal government and the normalisation of coercive government in Aboriginal Affairs policy. Describing policies as neoliberal has provided critics with a mechanism for linking particular examples of governance to a broader nationwide, or even global, system of ideological hegemony and political domination. The process of connecting policy to global hegemonies can, however, make the case for coercive government appear more coherent than it really is. This is because we come to understand the politics of the NT Intervention as part of a global system of power, which because of its size and influence, is virtually unassailable.

I reorient the discussion of the intervention to focus on the ways in which the broader tropes of neoliberal governance have been incorporated into the legitimising discourses surrounding the intervention in specific ways. As pointed out by Kendall Phillips, discursive formations are riddled with incoherence and contingency, but they work to give the overall impression of 'authority and absoluteness' (2002: 333). It is the 'contradictions' within discourse that provide a space for freedom - in the Foucauldian sense - as an opportunity for dissension and, consequently, the development of new kinds of knowledge, subjectivity and power relations (Phillips 2002: 336-37). In the remaining sections of this chapter I sketch out two examples of the ways in which common neoliberal tropes have been actively reworked in order to produce new types of knowledge. The knowledge produced in this manner positions Aboriginal people as deficient and, therefore, as appropriate targets for intensive government. This analysis is informed by Foucault's later work on liberal governmentality, which understood government as any deliberate attempt to systematically shape human conduct (Dean 2010: 18). I also explain why the production of this kind of knowledge might have contributed to the normalisation of coercive power relations. 


\section{Neoliberal subjects: A summary of politicians' statements about desirable attitudes and conduct among Aboriginal people}

Many people are familiar with Foucault's work on the production of the subject, including his arguments about the relationship between knowledge and disciplinary forms of power in the early modern period (1977). His later work built on these ideas and focused on government as a new form of power that had 'population as its target, political economy as its major form of knowledge, and apparatuses of security as its essential technical instrument' (2008: 109). Existing alongside earlier forms of power, such as sovereignty and discipline, government sought to 'conduct ... the conduct of men' and applied a new body of social scientific knowledge about economics, society and populations to the management of the whole social body (Foucault 2007: 107-08; 2008: $108,86)$. The concept of governmentality is a useful one because it provides a means of connecting the production of knowledge about populations as the subject of attempts to govern - to discourses about what constitutes good and effective government. In the case of the NT intervention, I show that legislators borrowed familiar tropes about, first, the capable neoliberal subject and second, about the failures of the welfare state. Legislators employed these tropes to produce knowledge about Aboriginal communities. In this section I look at parliamentarians' statements about Aboriginal people. I argue that these statements draw on a broader neoliberal conception of the capable subject to produce knowledge about the deficiencies of Aboriginal people.

First, I need to outline what I mean by the capable subject and how this is related to neoliberal forms of reasoning or governmentality. Since there is no universal standard by which we can judge conduct, it is necessary to acknowledge that there are a multiplicity of rationalities — or governmentalities - which draw on, and produce, different kinds of knowledge in order to develop different understandings about what constitutes good and effective government (Dean 1999: 19). Against this general background, scholars of governmentality have sought to understand how different strands of liberal thought employ different understandings of effective government, individual liberty and the appropriate relationship between the individual and state (Dean and Hindess 1998: 12). For instance, welfarist rationalities for political rule arose as a formula for liberal government that sought to guarantee individual wellbeing against the vagaries of a market system, while simultaneously securing the liberties required for capitalist enterprise. This mode of social government incorporated a variety of programs and technologies of government including tax regimes, social insurance, employment agencies, and state intervention in the economy (Rose 1993: 291-93). In contrast, neoliberal rationalities of government seek to liberate 
populations from dependency on state welfare and public services. While neoliberals deplore 'big government', scholars of governmentality have pointed out that neoliberalism is not necessarily any less interventionist than other forms of liberal government. Neoliberals often emphasise the need to construct the artificial, but nonetheless necessary, conditions that make the market, and good outcomes, possible (Donzelot 2009: 28-30; Watson 2004: 587-88). For instance, many neoliberal programs attempt to deliver health, employment, education and similar services via market arrangements rather than through social technologies such as nationalised health (Hindess 2002: 140).

The above examples of governmentalities are only general types, and there is much variation on these basic themes. Nonetheless, a focus on these broad types can help us to identify how proponents of different strands of liberal thought have developed different and competing conceptions of the ideal citizen. Welfarist rationales for rule have generally focused on the ideal of a national community of 'thrifty, industrious and socially responsible' male breadwinners and female domestic workers. In contrast, neoliberal forms of rationality shift the target of government intervention toward the production of active, autonomous and entrepreneurial individuals. The capable neoliberal citizen is primarily a responsible individual who manages risk by purchasing private insurance against unemployment, ill health or disability, and who actively develops their human capital in ways that will help them to compete in the labour market and optimise the quality of life for themselves and their families (Donzelot 2009: 29; Larner 2000: 13; Rose 1993: 296; Rose and Miller 1992: 192-200). It is this second set of capabilities that structured discourse about Aboriginal people during the NT Intervention debates.

This discourse took three main forms. First, legislators argued that Aboriginal people should adopt the attitudes and behaviours that are necessary for success in a free market economy. Country Liberal Party MP David Tollner illustrates this idealisation of the free market economy when he argues that Aboriginal Australians need to have access to 'real property rights' so they can 'buy a home ... own a piece of land ... [and] start businesses'. His ideal also incorporates a vision of small-scale entrepreneurship in which every community includes 'a market garden, a greengrocer, a hairdresser, a restaurant, a clothing shop, a shoe shop, a bakery or a butcher shop' (Parliament of Australia 2007: 96-97). When the Labor Minister for Indigenous Affairs, Jenny Macklin, speaks of Aboriginal parents being 'the best role model possible' for their children she is clearly referring to the role they should play as participants in a mainstream economy and labour market (Macklin 2009a). On a separate occasion, Labor Prime Minister Julia Gillard made a 'call for changes in behaviour' and urged Aboriginal people to behave in responsible ways. She asked Aboriginal people to 'take care of your children; to take a job when you find one; to create a safe environment; to send 
your kids to school, pay your rent, save up for a home; to respect good social norms and to respect the law' (Karvelas 2011). The behaviour outlined here bears a close resemblance to the neoliberal conception of the responsible citizen.

Second, the discourse emphasised the deficiencies of Aboriginal people. A closer examination of one aspect of the NT Intervention, the Income Management (IM) regime, reveals the strength of the view that Aboriginal people were irresponsible and incapable of managing their own affairs. The IM regime diverted 50 per cent of individuals' regular fortnightly social security payments, and 100 per cent of all lump sum payments such as the Baby Bonus, to a special management account. This allowed government to direct Aboriginal individuals' expenditure, including the type of items individuals could buy - for example, food, beverages, clothing, household items, housing, and childcare - and where they could buy them (Human Rights and Equal Opportunities Commission (HREOC) 2008: 270). According to Liberal Party MP David Fawcett, IM was developed in 'recognition that there is a small subset within our community who, for whatever reasons, have not developed the life skills, the motivation or the ability to manage their own circumstances and the circumstances of those whom they have responsibility for' (Parliament of Australia 2007: 111). IM received almost universal support from parliamentarians, suggesting that Fawcett's views were unexceptional. Indeed, IM featured as a prominent aspect of later Labor government policy in the Northern Territory, where it was seen as necessary to prevent the purchase of harmful substances, such as alcohol (Macklin 2009b).

The final aspect of the discourse on the NT's Aboriginal population focused on the idea that Aboriginal culture was an obstacle to development and probably responsible for the deficiencies of Aboriginal individuals. This type of justification was most explicit among politicians of the Liberal-National coalition. Former Liberal MP Barry Haase, for instance, problematised Aboriginal culture by making explicit comparisons between an Aboriginal and mainstream 'style of life'. He argued that some of the 'cornerstones of our mainstream society', including respect for education, the rule of law, and an acceptance of personal responsibility, were non-existent in many Aboriginal communities (Parliament of Australia 2007: 102-03). Minister for Indigenous Affairs Mal Brough also focused on the social context of problems in Aboriginal communities. He argued that 'normal community standards and parenting behaviours' had broken down in some remote Aboriginal communities. He attributed this breakdown to the lack of economic activity and the availability of 'free money' in the form of welfare (Parliament of Australia 2007: 2). Labor parliamentarians also employed this rationale for the Intervention. For example, Prime Minister Kevin Rudd referred to the 'manifest failures on the part of [Aboriginal] individuals and communities' 
and to the 'dysfunctional culture of violence and neglect that blights some communities' (Rudd 2009). This type of analysis associates the problems in Aboriginal communities with wider cultural and behavioural norms.

Taken together, these three elements of discourse contributed to the view that Aboriginal people fall below socially acceptable norms of behaviour. This way of representing Aboriginal people incorporates elements of recognisably neoliberal reasoning - namely, its view of desirable capabilities and behaviour — but the use of these ideas to position Aboriginal people and culture as deficient is a product of the particular discourse of the intervention itself. This is not the first time that free market ideology has been used to position Aboriginal people in this way. Scholars have previously noted the way that neoliberal free market ideology had already 'infiltrated' the 'fabric of Indigenous life'. In the past this has seen many attempts to normalise the Aboriginal population by replacing concerns for 'custom, kin and land' with 'individualist aspirations of private home ownership, career and self-improvement' (Hinkson 2007; Walter 2010: 121-23).

\section{Neoliberalism and the problematisation of Aboriginal land tenure and employment projects}

The justifications for the NT Intervention not only involve the production of new knowledge about Aboriginal people's capacity for responsible behaviour, but also a critique of former approaches to Aboriginal governance. In this section I analyse parliamentarians' statements about two areas of policy: the land tenure system and Community Development Employment Projects (CDEP). I argue that the policies of the pre-Intervention period were associated, in the minds of many politicians, with an increase in welfare dependency among Aboriginal people, and with poor economic and social outcomes for Aboriginal people. This narrative of policy failure draws on the neoliberal critique of welfarist government and is used by politicians to explain the lack of steady progress in Aboriginal Affairs policy. This narrative results in the classification of past policy approaches, including rights-based approaches, as obstacles to Aboriginal welfare.

Before looking at specific policies, I note the general narrative about the failure of past policies in Aboriginal Affairs policy. Brough summarised the situation of the NT Intervention in the following manner: 'When confronted with a failed society ... [d]o we respond with more of what we have done in the past? Or do we radically change direction with an intervention strategy matched to the magnitude of the problem?' (Parliament of Australia 2007: 10). This rhetorical question demonstrates that the Intervention was understood as part of a deliberate and necessary shift in policy approach. For Brough and 
his parliamentary colleagues, these major reforms removed artificial obstacles to development in Aboriginal communities. In his words, the Intervention was designed to 'break the back of violence and dysfunction' and 'allow us to build sustainable, healthy approaches in the long term'. The NT Intervention was compared to an 'emergency surgery' that was required after a long period of ineffective 'bandaid' solutions (Parliament of Australia 2007: 12). Labor politicians were less focused on the narrative of policy failure but nonetheless tied their support of the Intervention to the poor conditions in Aboriginal communities (Parliament of Australia 2007: 107-08). Bipartisan support for the Intervention suggests that earlier approaches to Aboriginal Affairs were considered problematic by members of both the Coalition and Labor parties.

\section{Land tenure and rights}

Politicians demonstrated particular antipathy to recognition of Aboriginal difference, including departures from conventional conceptions of economic development. Aboriginal land rights were directly linked, in the political discourse, with poor economic development in Aboriginal communities. The Aboriginal Land Rights (Northern Territory) Act of 1976 allows for the communal freehold ownership of land by Aboriginal groups who can demonstrate a traditional and ongoing connection to that land. The Act guarantees Aboriginal participation in decisions about land use - such as mining and other industry on Aboriginal land - and gives Aboriginal owners control over access to their land through a system of permits administered by land councils (Central Land Council).

These land rights, particularly the permit system, were seen as problematic by Brough and his parliamentary colleagues. Brough argued that the land tenure system on Aboriginal lands was an obstacle to the development of a 'real economy' (Parliament of Australia 2007: 11). His analysis of the situation was as follows:

Banks will not lend money to start up small businesses because a committee [i.e. the Land Council] decides what tenure arrangements will apply. People cannot even borrow to buy their own home because they cannot own or lease a block of land. And to cap it all off, these towns have been closed to outsiders because of the permit system (Parliament of Australia 2007: 11-12).

Tollner developed a similar critique of land rights that described the Act as being about the 'preservation of culture' rather than 'good land management, land administration or planning for the future exploitation and productivity of the land' (Parliament of Australia 2007: 96-97). Like Brough, Tollner understood the land rights system as detrimental to Aboriginal people's economic prospects. Aboriginal control of land use had, according to Tollner, 'reduced Aboriginals to a welfare dependency status'. He argued that a powerful Aboriginal elite 
dominated decision-making in Aboriginal communities and distributed funds to 'select groups and individuals on a grace-and-favour basis, with little flowing down to those at the bottom' (Parliament of Australia 2007: 97).

Communal ownership and management of resources by Aboriginal people was, therefore, viewed as inherently problematic. They not only reduced the prospect of Aboriginal individuals engaging in a market economy but, according to the logic of Brough and Tollner, made this type of engagement practically impossible for individuals living on Aboriginal land. The distinctiveness of Aboriginal land tenure and, related to this, community governance arrangements, was a problem for politicians of all major parties. Both Coalition and Labor MPs repeatedly emphasised that their goal was to transform Aboriginal communities into normal suburbs. For instance, in June 2007, Howard declared that 'normalisation' was one of the main goals of Commonwealth involvement in Aboriginal communities, and there are references in the parliamentary debates on the NT Intervention to 'normal community standards' and 'normal suburbs' (Howard and Brough 2007; Parliament of Australia 2007: 2, 14, 74). In 2009, Macklin summarised the Labor government's goals for Aboriginal communities in the following terms:

Our benchmark will be to progressively deliver in communities or townships the facilities and services you would expect in an Australian town of the same size. The same infrastructure and services that support and sustain healthy social norms so people can reach their potential and businesses can thrive. So children grow up safe and healthy and go to school; where they have the best role model possible - a parent who goes to work each day. So children see their parents taking responsibility for the family's economic security and planning and providing for the future (Macklin 2009a).

This type of statement suggests that the future of Aboriginal communities should, in all important respects, be identical to that of non-Aboriginal Australians.

The NT Intervention included a number of measures designed to counter the power of land councils. The legislation for the Intervention dismantled the permit system for townships on Aboriginal land and roads into towns (though not for uninhabited Aboriginal land). It also included a measure for compulsory leasing of Aboriginal towns to the Commonwealth Government so that government agencies could deliver services without negotiating leases with land councils (Hinkson 2007: 1-2; Parliamentary Library 2007). By February 2008 these leases applied to a total of 64 communities (Department of Families 2009). These communities were managed in accordance with the community governance provisions outlined in the NT Intervention legislation. For example, 
government business managers were appointed to manage government-funded social and building programs, and there was a new prohibition on alcohol and pornography (Yu, Duncan and Gray 2008: 25).

\section{CDEP versus 'real jobs'}

Like land rights, the CDEP program, which had existed in various incarnations since 1977, came under fire for being part of a failed policy approach. The scheme straddled the divide between welfare and work by enabling Aboriginal groups to employ Aboriginal individuals to work part-time on projects of importance to local Aboriginal people. Individuals were paid a wage equivalent to the Commonwealth social security benefit, to which they would have been entitled if they were unemployed (Sanders 1997: 2-3). The abolition of CDEP and the transition to 'real jobs, training and mainstream employment services' was an important aspect of the NT Intervention legislation (Parliament of Australia 2007: 7). ${ }^{1}$ Brough justified the abolition of CDEP by arguing that, while CDEP had been a significant source of funding for Aboriginal communities, it had 'not become a pathway to real employment'. He argued that CDEP was 'another form of welfare dependency for many people' (Parliament of Australia 2007: 7). CDEP was therefore understood as an obstacle to Aboriginal individuals' participation in a mainstream labour market.

CDEP was also viewed as a structural problem that was preventing Aboriginal people developing the capabilities necessary for a good life. Haase and National MP Ian Causley both defined Aboriginal people's success in life in terms of their suitability for and engagement with the employment market. Haase argued that CDEP was a sort of 'furphy' employment, which was contributing to social problems in Aboriginal communities (Parliament of Australia 2007: 102-03). He suggested that 'real' employment would benefit Aboriginal people because it would foster individual skills and attitudes, such as a sense of responsibility, financial independence and self-esteem (Parliament of Australia 2007: 102-03). Causley provided a similar analysis when he argued that the problems in Aboriginal communities could be attributed to unemployment, and that Aboriginal people lacked the education and skills to find employment (Parliament of Australia 2007: 104-05). Indeed, for both Causley and Haase the employment market was considered a site for training Aboriginal people. The availability of real employment was crucial, from their perspective, because it could help individuals build the capabilities for engagement in the economic

1 The transition to mainstream unemployment services, such as work for the dole, was meant to be complete by July 2008, however, the CDEP scheme was maintained by a Labor government until July 2013, when the Remote Jobs and Communities Program (RJCP) came into operation (Department of Education 2011: 3-4). 
system as well as develop proper attitudes, such as a respect for education, a sense of personal responsibility and respect for the rule of law (Parliament of Australia 2007: 102-05).

\section{The welfare state critique}

Both CDEP and land rights were viewed as part of an earlier political paradigm that had focused on Aboriginal self-determination as an essential prerequisite for Aboriginal wellbeing. By 2007, however, there was strong antipathy toward this policy approach. The problematisation of this earlier policy approach often required a retrospective redefinition of the purposes of legislation so that it could be deemed a failure. For example, the Land Rights Act had been developed with the objective of maintaining the spiritual link between Aboriginal people and their land, and was never expected to ensure the economic development of Aboriginal people. ${ }^{2}$ The focus on the economic development of land, on individual rather than communal land ownership, and on access to 'real' rather than CDEP jobs stemmed from an increasingly narrow conception of development, which focused on the centrality of the market economy to the production of capable citizens and functional communities.

The political discourse on the NT Intervention - including the critique of land rights legislation and CDEP — drew upon the now-familiar neoliberal critique of the welfare state. The accusation that former approaches to Aboriginal government contributed toward welfare dependency and social disorder is a distinctive component of neoliberal criticisms of welfare. Parliamentary critique of earlier approaches to policy had much in common with the views of free market think tanks, such as the Centre for Independent Studies (CIS). The CIS has long campaigned for the end of so called 'separatist' policies in Aboriginal Affairs governance. Its campaign involved arguments for closing down 'unviable [Aboriginal] communities', replacing communal forms of land ownership and management with individual freehold property rights, and removing CDEP and other 'pretend jobs' (Hudson 2009; Hughes and Hughes 2010; Hughes, Hughes and Hudson 2010; Walter 2010: 126-27). In the remainder of this paper I consider how the problematisation of both Aboriginal behaviour and past Aboriginal Affairs policy contributed to bipartisan support for the more coercive measures of the NT Intervention.

2 For instance, the 1974 royal commission on land rights acknowledged that white Australians had already settled on most arable land and that land available to be claimed by Aboriginal people was economically unproductive (Woodward 1974: 2, 9-10). 


\section{Coercive governance and Aboriginal Affairs policy: A new norm?}

Previous scholarship on the NT Intervention addressed its neoliberal character but did not consider the important issue of how coercive government was justified by political elites. Given the bipartisan support for the Intervention, and the continuation of many of the coercive measures of the NT Intervention as part of the Stronger Futures scheme, it is important to consider the process of political reasoning that has made coercive policies acceptable to recent governments. My goal in this chapter has been to deepen our understanding of the way in which knowledge and power are linked in recent discourse on the NT Intervention. I have been concerned with the role of neoliberal tropes, such as responsible citizenship and the dangers of the welfare state, in the production of knowledge about Aboriginal people and Aboriginal community governance. I conclude this chapter with a few comments about the relationship between this discourse and the normalisation of coercive approaches to governance in this field. I suggest that justifications for coercive government employed aspects of neoliberal reasoning and governmentality, but that this reasoning was incorporated in an incomplete and patchy manner. This has meant that the NT Intervention relied on an incoherent and contradictory logic.

My explanation for this claim depends, once again, on the concept of governmentality. There are two relevant points here. The first relates to the nature of freedom and coercion in liberal government. Foucault argued that good government, from a liberal perspective, is government that manages the conditions of liberal freedom and fosters these conditions among the population (Foucault 2008: 61-68). This means that liberty is understood in functional rather than doctrinal terms, and only has value where it secures rather than inhibits prosperity and wellbeing. Since liberty is seen as a prerequisite for good outcomes, it makes sense that desirable liberties should be developed wherever they are seen to be lacking. Scholars of governmentality have pointed out that both facilitative and coercive forms of government are applied to the task of shaping individuals so they can govern themselves. For instance, the task of helping people get 'job ready' may involve facilitative skills-development programs run by government or non-profit organisations, as well as more coercive, involuntary programs which oblige unemployed people to contribute time and labour to approved organisations (Dean 2002: 38-41). In this context, we should understand coercion as a common technique for the production of capable liberal subjects.

The second relevant point is that coercive techniques of government have historically been applied in an uneven manner. Liberals have a tendency to draw upon coercive techniques of government where populations are perceived to 
lack the capabilities required for self-discipline, or where facilitative approaches to government are considered unlikely to be successful. In general, social scientific and other forms of expert knowledge are used to group liberal subjects according to their capacities for autonomy. The most autonomous individuals require little active government because their capacity for self-discipline allows them to conduct themselves appropriately within society and the economy. Other individuals, such as the unemployed or children, require help to acquire the necessary skills and capabilities for autonomous living (Dean 2002: 48). Historicist views, which see Indigenous people as falling below widely accepted norms for development, have increased the tendency to classify Indigenous people as part of a broader population of people - including criminals, immigrant communities and the urban poor - who are deemed to be incapable of self-discipline. This type of classification supports claims that Indigenous people require additional help, either facilitative or coercive, to learn how to conduct themselves appropriately (Hindess 2001: 365-71; 2004: 28-31).

Justifications for coercive government, therefore, depend on two prerequisites; political discourse must position a particular population as incapable of selfdiscipline, and simultaneously explain why more facilitative approaches to government would be unlikely to succeed in the task of governing this population. My analysis in this chapter suggests that both of these conditions are present in the political discourse of the NT Intervention. Politicians made it clear that they viewed Aboriginal people's behaviour, attitudes and skills as deficient and below the minimum standards expected of autonomous neoliberal citizens. The problematisation of past policy approaches in Aboriginal Affairs - which I have compared to the neoliberal critique of the welfare state - led legislators to doubt the utility of more facilitative strategies of government. As I mentioned above, CDEP, community governance provisions, the permit system and Aboriginal people's discretion to spend social security income according to their own preferences were all considered to be impediments to economic development. Since the chance of gaining voluntary participation in the new political agenda was low, both the Coalition and Labor governments considered coercive forms of governance to be justifiable and necessary.

What are the implications of this analysis for our understanding of the relationship between neoliberal government and coercive strategies of government? Based on this case study alone, there is no compelling reason to consider neoliberalism as more innately coercive than other strands of liberal government. Neoliberal tropes were used selectively in the production of knowledge about Aboriginal people, and the broader context of governance, in the Northern Territory. It is possible that many other standards of ideal citizenship and good government could have been used in a similar manner to position Aboriginal citizens and their communities as deficient and in need of intervention. The exact nature 
of this critique would have been different, but the effect on the relationship between Aboriginal and non-Aboriginal peoples might have been similar. In some respects, the discourse of the NT Intervention merely reproduces a longstanding tendency to target Aboriginal people for intensive intervention and reform. Neoliberal forms of argument can take their place among many other historical justifications for colonial government.

This does not mean that the neoliberal discourses of the Intervention should not be interrogated. The primary implication of my analysis in this chapter is that critics of the current approach to Aboriginal Affairs governance should address ideas about the cultural deficiency of Aboriginal people and the particular language of policy failure that has become common in recent years. The representations of Aboriginal people produced by these discourses are widely accepted and are being used to structure power relations in such a way that the views of Aboriginal people are almost completely dismissed unless they accord with the current political agenda. The current discourse also positions Aboriginal culture as an obstacle to the development and wellbeing of Aboriginal people, thereby paving the way for the forceful assimilation of Aboriginal people into the Australian cultural and economic mainstream. In this context, it is possible to point toward some of the less coherent aspects or implications of the current discourse. To provide one example, it is illogical to conflate all former policy approaches in Aboriginal Affairs governance with a failed welfare state regime. As Tim Rowse has pointed out, the initial impetus for Aboriginal self-determination could itself be considered part of a neoliberal reform agenda (Rowse 1996).

Another incoherency that might be capitalised on by critics is the difficulty of producing viable strategies for government that are consistent with current definitions of the policy problem. There is no obvious method available, based on current discourse, for the actual production of capable citizens. Intensive forms of regulation, such as the IM regime, may discipline individuals and ensure they act in certain ways. They are unable, however, to bring about the substantive changes in attitude that would, presumably, be required to produce capable, fully functioning neoliberal citizens. The usual neoliberal techniques for achieving this are unlikely to work in Aboriginal communities. The construction of quasi-markets for the delivery of formerly public services has been one common way of helping to boost the capabilities of individuals in non-Indigenous contexts. For instance, the Australian Government replaced public job creation and employment services with a competitive market of private and community sector job placement enterprises in the mid-1990s. The ethos of this quasi-market based delivery of social services is that clients can learn the norms and values of the market - such as initiative, responsibility, and competitiveness - through the experience of choosing between a range of 
private service providers. They can then apply these skills in real job markets (Dean 2010: 187-89). In remote Aboriginal communities, however, it would be enormously difficult to develop such quasi-market schemes as there are too few private and community sector organisations to develop a competitive marketplace for the provision of social services. The current discourses about Aboriginal governance lead to no viable plan for producing the outcomes that proponents claim to be desirable and necessary, and this makes these discourses both unstable and vulnerable.

To conclude, coercive government is more likely in situations where individuals are understood to lack important capabilities for success, and where facilitative approaches to government are seen as unlikely to achieve governance objectives. In this chapter I have presented a critical analysis of the rhetoric of the NT Intervention with the goal of destabilising the authority of those discourses which legitimate and normalise coercive approaches to Aboriginal Affairs governance. Drawing on the concept of governmentality, I demonstrated that Aboriginal people were perceived to be incapable of living an autonomous existence because of a lack of personal responsibility and skills. Aboriginal communities were also seen as falling short of the norms of mainstream society, with parliamentarians producing a powerful narrative that conflated past policy approaches with the failed welfarist approach in public policy. This narrative created new knowledge about the social conditions in Aboriginal communities, including a view that Aboriginal communities were dysfunctional and provided an insufficient environment for the development of capable, independent individuals. In this context, coercive government was seen as a necessary aspect of the plan to remove obstacles to the development of market economies in Aboriginal communities. This detailed understanding of the operation of knowledge/power in current political rhetoric opens up opportunities for a more targeted critique of the coercive aspects of Aboriginal Affairs policy.

\section{References}

Altman, J. 2007. The 'National Emergency' and land rights reform: Separating fact from fiction. An assessment of the proposed amendments to the Aboriginal Land Rights (Northern Territory) Act 1976. Centre for Aboriginal Economic Policy Research (CAEPR), Canberra. URL: http://caepr.anu.edu. au/sites/default/files/Publications/topical/Altman_Oxfam.pdf. Consulted 28 November 2013.

Anderson, I. 2008. Indigenous Australians and health rights. Journal of Law and Medicine 15: 760-72. 
Australia, Parliament of 2007. Parliamentary debates. House of Representatives Official Hansard 11 (7 August). Canberra.

Australian Government 2011. Stronger futures in the Northern Territory: Policy statement. November. Canberra.

Biesecker, B. 1992. Michel Foucault and the question of rhetoric. Philosophy \& Rhetoric 25(4): 351-64.

Cahill, D. 2007. The contours of neoliberal hegemony in Australia. Rethinking Marxism 19(2): 221-33.

Central Land Council, The Aboriginal Land Rights Act, URL: http://www. clc.org.au/Ourland/land_rights_act/Land_rights_act.html. Consulted 24 September 2011 .

Concerned Australians 2010. This is what we said: Australian Aboriginal people give their views on the Northern Territory Intervention. East Melbourne.

Conor, L. 2007. Howard's desert storm. Overland 189: 12-15.

Cooper, M. 1988. Rhetorical criticism and Foucault's philosophy of discursive events. Central States Speech Journal 39(1): 1-17.

Dean, M. 1999. Governmentality. Power and rule in modern society. London: SAGE Publications.

2002. Liberal government and authoritarianism. Economy and Society 31(1): 37-61.

2010. Governmentality. Power and rule in modern society. 2nd edn. Los Angeles: Sage.

Dean, M. and Hindess, B. 1998. Introduction: Government, liberalism, society. In M. Dean and B. Hindess eds. Governing Australia. Studies in contemporary rationalities of government. Melbourne: Cambridge University Press.

Department of Education, Employment and Workplace Relations 2011. The future of remote participation and employment servicing arrangements: Discussion paper. Canberra.

Department of Families, Community Services and Indigenous Affairs 2009. Five year leases on Aboriginal land. URL: http://www.fahcsia.gov.au/sa/ indigenous/progserv/ntresponse/about_response/housing_land_reform/ Pages/five_year_leased_aboriginal_land.aspx. Consulted 1 October 2010.

Dodson, P. 2007. An entire culture is at stake. Age (Melbourne) 14 July: 9. 
Donzelot, J. 2009. Michel Foucault's understanding of liberal politics. In M.A. Peters, A.C. Besley and M. Olssen eds. Governmentality studies in education. Contexts of education. Rotterdam: Sense Publishers.

Foss, S.K. and Gill, A. 1987. Michel Foucault's theory of rhetoric as epistemic. Western Journal of Speech Communication 51(4): 384-401.

Foucault, M. 1977. Discipline and punish. London: Allen Lane.

2007. Security, territory, population. Lectures at the College De France 19771978. Basingstoke: Palgrave Macmillan.

2008. The birth of biopolitics. Lectures at the College De France 1978-1979. Basingstoke: Palgrave Macmillan.

Hindess, B. 2001. Not at home in the Empire. Social Identities 7(3): 363-77.

2002. Neo-liberal citizenship. Citizenship Studies 6(2): 127-43.

2004. Liberalism: What's in a name? In W. Larner and W. Walters eds. Global governmentality: Governing international spaces. London: Routledge.

Hinkson, M. 2007. Introduction: In the name of the child. In J. Altman and M. Hinkson eds. Coercive reconciliation. Stabilise, normalise, exit Aboriginal Australia. Melbourne: Arena Publications.

Howard, J. 2007. To stabilise and protect - Little children are sacred, address to The Sydney Institute, 25 June, The Sydney Papers 19(3): 68-76.

Howard, J. and Brough, M. 2007. Joint press conference with the Hon. Mal Brough, Minister for Families, Community Services and Indigenous Affairs. Prime Minister of Australia: Media centre. URL: http://pandora. nla.gov.au/pan/10052/20080118-1528/pm.gov.au/media/Interview/2007/ Interview24380.html. Consulted 25 June 2008.

Hudson, S. 2009. From rhetoric to reality: Can 99-year leases lead to homeownership for Indigenous communities? St Leonards: Centre for Independent Studies.

Hughes, H. and Hughes, M. 2010. Indigenous employment, unemployment and labour force participation: Facts for evidence based policy. St Leonards: Centre for Independent Studies.

Hughes, H., Hughes, M. and Hudson, S. 2010. Private housing on Indigenous land. St Leonards: Centre for Independent Studies.

Human Rights and Equal Opportunities Commission (HREOC) 2008. Social Justice Report 2007. Sydney. 
Karvelas, P. 2011. 'Gap won't close if you don't act': Julia Gillard. Australian 10 February. URL: http://www.theaustralian.com.au/national-affairs/gapwont-close-if-you-dont-act-julia-gillard/story-fn59niix-1226003313411. Consulted 15 February 2011.

Larner, W. 2000. Neo-liberalism: Policy, ideology, governmentality. Studies in Political Economy 63: 5-25.

Macklin, J. 2009a. Importance of delivering remote Indigenous housing in an efficient and affordable way - Delivering Indigenous housing, Speech, 15 September. URL: http:/www.jennymacklin.fahcsia.gov.au/speeches/2009/ Pages/speech_indig_19aug09.aspx. Consulted 30 September 2010.

2009b, Strengthening the Northern Territory Emergency Response. Joint Media Release with Warren Snowdon MP, Member for Lingiari. 25 November. URL: http://www.jennymacklin.fahcsia.gov.au/mediareleases/2009/Pages/ strengthening_nter_25nov2009.aspx. Consulted 14 February 2011.

Macoun, A. 2011. Aboriginality and the Northern Territory intervention. Australian Journal of Political Science 46(3): 519-34.

Manderson, D. 2008. Not yet: Aboriginal people and the deferral of the rule of law. Arena Journal 29/30: 219-72.

Mazel, O. 2009. Development in the 'First World': Alleviating Indigenous disadvantage in Australia - The dilemma of difference. Griffith Law Review 18(2): 475-502.

McKerrow, R.E. 1989. Critical rhetoric: Theory and praxis. Communication Monographs 56(2): 91-111.

Parliamentary Library. 2007. Northern Territory National Emergency Response Bills 2007 — Interim Bills Digest. Canberra: Parliament of Australia. URL: http://www.aph.gov.au/binaries/library/pubs/bd/2007-08/08bd018.pdf. Consulted 28 November 2013.

Phillips, K.R. 2002. Spaces of invention: Dissension, freedom, and thought in Foucault. Philosophy \& Rhetoric 35(4): 328-44.

Rose, N. 1993. Government, authority and expertise in advanced liberalism. Economy and Society 22(3): 283-99.

Rose, N. and Miller, P. 1992. Political power beyond the state: Problematics of government. The British Journal of Sociology 43(2): 173-205. 
Rowse, T. 1996, 'Neo-liberal/Advanced liberal tendencies in contemporary Aboriginal Affairs', paper presented to Culture and Citizenship Conference, Griffith University, Brisbane, Australia, 30 September -2 October.

Rudd, K. 2009. Closing the Gap Report. Media release, 26 February. URL: http:// pmrudd.archive.dpmc.gov.au/node/5287. Consulted 14 February 2011.

Rundle, G. 2007. Military humanitarianism in Australia's north. In J. Altman and M. Hinkson eds. Coercive reconciliation. Stabilise, normalise, exit Aboriginal Australia. Melbourne: Arena Publications.

Said, E.W. 2003. Orientalism. London: Penguin Books.

Sanders, W. 1997. Opportunities and problems astride the welfare/work divide: The CDEP scheme in Australian social policy. Canberra: Centre for Aboriginal Economic Policy Research (CAEPR).

Tangentyere Council 2007. Work with us, not against us. Press release. URL: http://www.tangentyere.org.au/publications/\#press_releases. Consulted 29 October 2010.

Walter, M. 2010. Market forces and Indigenous resistance paradigms. Social Movement Studies: Journal of Social, Cultural and Political Protest 9(2): 121-37.

Watson, V. 2004. Liberalism and advanced liberalism in Australian Indigenous affairs. Alternatives: Global, Local, Political 29(5): 577-98.

Woodward, A.E. 1974. Aboriginal Land Rights Commission. Second report. Canberra: The Government Printer of Australia.

Yu, P., Duncan, M.E. and Gray, B. 2008. Northern Territory emergency response. Report of the NTER Review Board. Canberra: Attorney-General's Department. 
This text taken from Studies in Australian Political Rhetoric, Edited by John Uhr and Ryan Walter, published 2014 by ANU Press, The Australian National University, Canberra, Australia. 